\title{
Does the Independent of Supreme Audit Institutions Matter on Good Governance? An Insight from Nigeria Auditor General for the Federation
}

\author{
Saheed Ademola Lateef ${ }^{1}$, Norfadzilah Rashid ${ }^{1, *}$, Abubakar Umar Farouk ${ }^{2}$, \\ Wahid Damilola Olanipekun ${ }^{3}$

\begin{abstract}
${ }^{1}$ Faculty of Business and Management, Universiti Sultan Zainal Abidin, Gong Badak Campus, Terengganu, Malaysia ${ }^{2}$ Department of Accounting, Yusuf Maitama Sule University Kano, Nigeria

${ }^{3}$ Department of Management and Accounting, Summit University Offa, Nigeria
\end{abstract}

Received November 16, 2020; Revised June 16, 2021; Accepted July 19, 2021

\begin{abstract}
Cite This Paper in the following Citation Styles
(a): [1] Saheed Ademola Lateef, Norfadzilah Rashid, Abubakar Umar Farouk, Wahid Damilola Olanipekun, "Does the Independent of Supreme Audit Institutions Matter on Good Governance? An Insight from Nigeria Auditor General for the Federation," Universal Journal of Accounting and Finance, Vol. 9, No. 4, pp. 712 - 721, 2021. DOI: 10.13189/ujaf.2021.090417.

(b): Saheed Ademola Lateef, Norfadzilah Rashid, Abubakar Umar Farouk, Wahid Damilola Olanipekun (2021). Does the Independent of Supreme Audit Institutions Matter on Good Governance? An Insight from Nigeria Auditor General for the Federation. Universal Journal of Accounting and Finance, 9(4), 712 - 721. DOI: 10.13189/ujaf.2021.090417.
\end{abstract}

Copyright $@ 2021$ by authors, all rights reserved. Authors agree that this article remains permanently open access under the terms of the Creative Commons Attribution License 4.0 International License

Abstract The Supreme Audit Institutions (SAI) are required to act as a corner stone in the public financial management system to prevent and discourage corruption by enhancing transparency, accountability and good governance. However, the executives and legislative arms of government in most of the African countries have reportedly overpowered the independence of SAI due to certain factors. Therefore, this study examines the factors hindering the independence of SAIs towards good governance in the Nigerian public sector. The primary data were collected from senior and management officers in the office of the Auditor General for the Federation and Public Account Committees of the National Assembly through self-administered questionnaire. One hundred and fifty (150) questionnaires were distributed to the respondents. The statistical analysis tool employed in this study is Structural Equation Modeling. The two hypotheses developed for this study were tested through regression analysis which indicated that both negatively affect good governance in the Nigerian public sector. The study revealed that the independence of SAIs in Nigeria was impaired in two critical areas; deliberate under-funding of SAIs and the quality of external auditor hired to perform the task. The study recommends that the constitutional provision that impairs the independence of SAIs should be repealed to ensure their financial autonomy. Finally, the study suggested that the Nigerian government should allow the SAI to independently determine the appointment of experienced external auditors and their fees.

Keywords Supreme Audit Institution, Independence, External Auditors' Quality, Good Governance, Nigeria

\section{Introduction}

The increasing public demand for accountability and transparency in the governance and management of public sector in several countries across the globe call for serious concern among academics and practitioners. Thereby, the global outcry against this extravagant and wasteful expenditure without regards to the effective utilization of public fund coupled with corruption is another serious issue of debate, which Nigeria is not an exemption $[1,2,3,4]$. As a result, lack of accountability in government provides opportunities for public fund wastage and corruption with attendant negative consequences to the 
economy of the country [5]. To such an extent, that budget which worth billions of dollar yielded little or nothing in terms of value added to the economy. Furthermore, due to the demand for democratic dividend and concern about corruption in the public sector, citizens request for adequate information about what political office holders intend to achieve and what has been accomplished so far $[6 ; 7,3]$.

Meanwhile, the Supreme Audit Institution (SAIs) which is regarded as Auditor General in Nigeria is expected to serve as an authority that saddles the responsibility of providing unbiased and objective assessment of whether public fund is effectively managed to achieve intended outcome. That is, the conduct of regular audits of public financial account is entrusted to the office of Auditor General who is recognized as the Supreme Audit Institution in Nigeria. In addition, the increase government wastage and ineffective governance by its agencies has brought enormous pressure on the supreme audit institutions to reduce this deficiency in order to promote good governance and economic development [3,7]. Despite the engagement of SAIs to assess and report the financial operations of all these agencies, corruption and other irregularities are still endemic. This continue to plague the country's economy; coupled with weak public health system, insecurity, poverty, poor infrastructure among other several challenges [53, 54]. However, numerous challenges also weaken the independence of SAIs to have effective performance in Nigeria. This includes insufficient funding, lack of knowledge and experience, supportive environment, adherence to international standards, appointment and promotion of SAI heads, among others [9,10,11].

Professionally, supreme audit institution is expected to be independent and apolitical in order to perform its constitutional role. This is done so as to ensure that public funds are properly utilized, effectively managed and publication of financial reports are made available periodically $[3,8]$. Unfortunately, the influence of political actors in the appointment and promotion of supreme audit institutions officers have hindered the independence of SAIs to perform its statutory duties; by examining how public funds are properly and efficiently managed. As revealed by the previous studies, the independence of SAI from the influence of corrupt politician is toiled in exchange for promotion and for the safeguard of their appointment $[12,3]$. This has impaired public expectation towards SAI in terms of combating fraud through prevention and detection of any form of corruption in the Nigerian public sectors.

In addition, the issue of under-funding is another major challenge facing the SAIs; where the institutions need to acquire the necessary equipment, hire experience and professionals to perform statutory task, hence lacks the fund to do so. This argument is consistent with the findings made in previous studies as the audit committee significantly influence the performance of the business organizations [13]. As stated by Inyang [9], the lower legislative arm of government (Federal House of Representative) accused the executive arms of deliberate under-funding of SAIs, where the house responded to the erratic reduction of the SAIs' budget from N1.9 billion to N100 million, when N16 trillion annually is illegally identified as extra budget spending. Any influence on SAIs independence due to the fund may impair the auditors' independence and negatively impact audit quality (i.e., when auditors' quality is impaired, the objective of SAIs will be compromised). This indicates that the independence of external auditors must be assured to enhance audit quality. To establish whether the independence of SAIs influence the effectiveness and efficiency of good governance of public sector, this study intends to examine the issue of under-funding and the quality of external auditor hired to perform such task. Therefore, the specific objectives of the study are stated as followed.

i. To examine whether the under-funding of SAIs affect their independence towards good governance in Nigeria.

ii. To examine whether external auditors' quality affect SAIs independence towards good governance in Nigeria.

\section{Review of Related Literatures}

\subsection{The Supreme Audit Institutions}

Supreme Audit Institutions (SAIs) is an important part of public financial management structure responsible for preventing and deterring corruption by improving transparency, accountability and good governance [4]. Also, the agency is an autonomous, competent, independent and non-political body established to provide mutual support, promote the exchange of ideas, expertise and knowledge; provide high quality auditing standards; promote good governance; and promote the growth of capacity and continuous improvement of results. SAIs is defined as the public body of a supranational institution by the International Organization of Supreme Audit Institutions [14] and is constituted, appointed and exercised by law. It is also the supranational organization's highest public auditing position with/without jurisdictional expertise in an independent way. Hence, this emphasized the hierarchical level of the SAI and the essence of its independence. Given the complexity of geographical territories, designations and system involved, it is explicitly clear that by definition, it relieves her of any political decision on how the SAI should operate [48].

SAIs promote good governance, as reported by Kayrak 
[4], by helping their government improve efficiency, ensure accountability, improve transparency, combat corruption, promote public confidence, preserve integrity, and promote the efficient use of public resources for the benefit of the people. They also make a positive difference to citizens' lives in three vital areas, according to INTOSAI [14]. These are:

- Strengthening the accountability, transparency, and integrity of government and the public sector entities.

- Establishing ongoing relevance to citizens, parliament and other stakeholders.

- It is being a model organization through leading by example.

The supreme audit institutions are central to governance reforms and achieving objective development goals and priority, most especially in developing nations of the world [15]. The United Nation resolution in 2014 emphasized their essence for accountability and transparency in the public sector and requested that member countries and international institutions (such as World Bank and IMF) to mandate SAI's operation. These development partners such as World Bank and IMF has emphasized this as conditional for financial support for most of developing countries $[1,16,9]$. The objective was to ensure the spending of public fund solely on development priorities, improve decisions, promote good governance, reduce corruption and irregularities, and monitor the effectiveness of aid against development goals $[17,18,19]$. Strengthening the developing countries became associated with establishing effective SAIs, specifically those not controlled by the executive arms of government [52]. Despite the growing work on accounting of developing countries, the operations of SAI only received little attention $(30,1,47]$.

In Nigeria, the SAI is designated under the Auditor General's office as stipulated by the 1999 constitution of Nigeria (Section 86 (1-3)). The head is appointed by President subject to the recommendation of the Federal Civil Service Commission on the confirmation of Senate [9]. Also, section 87(1\&2) stipulate the tenure of the office of Auditor General added with the condition for the removal from office. In addition, the Financial Regulation of Nigeria stated clearly that, the power of the Auditor General includes: power to carry out Ad-hoc investigation, request for the information and explanation; and access to the books and records of all MDAs [20]. Perhaps, the office is created by law to examine the general performance of government with freedom to access whether the accounts relating to the public funds are effectively and efficiently managed [51, 55].

Other legislative instruments aimed at ensuring effective and efficient performance of the Auditor General Office (as the Supreme Audit Institutions) are: the Audit Act (1956) as amended; the Financial Control and Management Act (1958) as amended. As the chairman of the Audit Alarm Committee, Section 85(4-6) of the
Nigerian constitution, SAIs are constitutionally allowed to investigate all statutory government corporations, authorities, departments, commissions, as well as all bodies constituted by the law of the National Assembly [21]. With regard to their oversight duties, the foresight services of SAI government auditors help ensure that public officials and political office holders uses the highest level of honesty to conduct public funds and assets transparently, honestly and reasonably. In the exercise of government policies, SAI often plays a role in identifying and disclosing abuse of power, corruption, and failure to provide due process. Since reporting may challenge the powerful officers (Politicians), SAIs requires some measure of protection to ensure independent report [9].

\subsection{Independence of SAIs}

With regard to the power separation between the three arms of government, SAIs are expected to be functional, financially and institutionally independent guaranteed by laws, constitutions and other relevant regulations since SAI cannot be classified as part of any arms of government [4]. The relationship between SAIs and the executive arms of government is proposed as follows, in accordance with the INTOSAI auditing standard in 2001:

- It is necessary for the independence of the SAI that the executive arms will have no power of direction in relation to the implementation of its mandate. In other words, the SAI shall not be obliged to carry out, update or refrain from carrying out an audit or to remove or amend audit results, recommendations and conclusions [22].

- Maintaining the independence of the SAI does not exclude proposals made to the SAI by the executive arms proposing audit matters. Yet adequate freedom is also to be appreciated. The SAI should be in a position to reject any such application. The principle of SAI independence also requires that decisions on audit tasks involving the programme must eventually be taken with the supreme audit institutions [22].

One of the most effective ways in which SAIs can promote and protect their independence, as recognised by INTOSAI, is by clearly and consistently demonstrating the value and benefits of SAIs and their work to promote good governance. In the meantime, INTOSAI Mexico (ISSAI 10) and Lima (ISSAI 1) have identified eight core roles and the independence principle of the supreme audit institution. This includes: legal status, personnel, SAI heads, activities, access to records, audit results reporting, audit report content and timing, and successful follow-up processes.

In Nigeria, Section 85(6) of Nigerian 1999 Constitution stipulated the independence of SAI in the exercise of their constitutional roles. The organisations shall not be subject to any authority's direction. As shown by Khan [23], there is a constitutional consensus that SAIs should play an 
important role in fostering good governance, openness and accountability. However, most of the SAIs in the developing countries still lack independence and insufficient resources to play their statutory role, particularly in Nigeria where one of the lawmakers revealed the inadequacy of SAIs independence as a result of under-funding the agency [9]. The role of SAIs under the legitimate scheme and its security of independence and tenure became questionable from Presidency as reported by Tell Magazine in 2003 (Tell Magazine, 2003). Despite the fact that the reports of the SAIs serve as an important tool for lawmakers to monitor the executive's dealings with public funds, there is nothing to suggest the political will of Parliament to pass legislation to safeguard the performance of this constitutional function by the SAIs [12, 19]. The study by Ijeoma and Nwufo [24] revealed that the SAI in Nigeria could not operate effectively as a result of the following challenges: inaction to audit queries, non-functional public accounts committee, constitutional limitation of the institution's functions, light punitive sanctions on codified offences, reliance of the Auditor-General on the Executive, late submission of the report and absence of a prosecuting authority. As mentioned above from the previous studies, the independent of SAI were hindered in Nigeria due to the under-funding of the institution; process of appointment to the SAIs office; and the quality of external auditors in the Supreme Audit Institution.

\subsection{The Theoretical Framework}

The argument of this study is anchored on the assumption that the process of appointing SAIs head, deliberate under-funding of the institution and quality of external auditors by the SAIs can impair SAIs from carrying out their statutory duties effectively to achieve their set objectives. The study therefore supported by agency theory and fraud diamond theory.

\subsubsection{Agency Theory}

The agency theory disclosed that individual pursue their self-interest when they are delegated and entrusted with responsibilities. As stated by Abdullah and Valantine [25], opportunistic behavior (self-interest) succumbed because the principal and the agent are having different aspirations and pursuits. This relates to the current study that Nigerians and federal government representative have principal-agent relationship where the resources of Nigerian are expected to be entrusted by the federal government in line with the constitutional provisions and financial regulations in the country. However, the principal does not have basis for trusting the agent since his interest and information are quite different from his agent [50]. Hence, the financial regulations and constitutional authority are to regulate the actions of the federal government [9]. Meanwhile, the lack of quality external auditors and under-funding of the institutions hindered the roles and responsibility of detecting fraud most especially at a time of increasing incidence of fraud which is highly questionable. This indeed creates a weakness since the federal government is responsible for deciding on what should be given to SAIs to perform their constitutional audit functions [26]. This is capable of protecting their financial interest, if they are involved in any financial fraud and other irregularities. Therefore, the study argued that the influence of the politicians on the appointment of SAIs officers and the deliberate under-funding of SAIs are capable of obstructing the SAIs from uncovering fraud and as such, this constitute a threat to the independence of SAI in Nigeria.

\subsubsection{Fraud Diamond Theory}

This theory was propounded by Wolfe and Hermanson [27] and it is an extension of fraud triangle theory by Donald Cressey [28]. This theory comprised of four elements that can prompt to committing fraud. This includes pressure, rationalization, opportunity and capability [29]. It was revealed that the interrelationship of these four elements can prompt an individual to commit fraud. This theory relates to this study because the federal government have been accused of influencing the appointment, promotion and deliberate under-funding the SAI because of their intention to commit fraudulent acts. This is because their budget is directly controlled by the federal government. The influence of appointment, promotion and deliberate under-funding of the SAI to enable the coverage of fraud is a function of opportunity, self-interest, rationalization and capability. This theory support the fact that underfunding the SAI at a time of increase in the fraud cases is a deliberate action and it is like trying to use one fraud to cover others. Hence, the devices used by the politicians to cover their frauds are stemmed from the pursuance of self-interest and this self-interest is implicit in the agency and fraud diamond theories are already explained.

\subsection{Hypothesis Development}

\subsubsection{Under-funding of SAIs and Good Governance}

The operation and smooth running of SAIs heavily relies on adequate funding. As reported by VanZyl et al. [48], SAIs are facing lack of capacity to effectively perform their constitutional functions. This is also related to the comments made by the World Bank report in 2001 that SAIs lack adequate funding, professional staffs and mandate to perform effectively and efficiently. They indicate that SAIs cannot monitor electronic transaction effectively and excluded from the public financial management. In addition, the poor channel of communication between or among the various stakeholders (such as, SAIs, civil society organizations, parliament, media, and the society at large) were also 
reported which reveals that their reports are rarely communicated to stakeholders. These incidences are usually lacking the contents of reports and somehow technical for people outside the accounting profession to comprehend SAIs financial report.

Poor funding, changes in political climate and technological influence have impeded the smooth running of the institution. As revealed by Wang and Rakner [31], the funding was not adequate in African countries, most especially in Nigeria and this eventually affects the capacity of SAIs to carry out their constitutional audit role effectively. They also revealed that the workload of SAIs increased without corresponding increase in their budgets, because the resource were determined by the executive arm of government. This study and other several studies conducted on the level of corruption and underfunding of the said agencies eventually hindered the good governance in Nigerian public sector [11, 10, 32]. Based on the evidence above, this study proposed the first hypothesis as follows:

$H_{l}$. There is a significant relationship between under-funding of the SAIs and good governance in Nigeria.

\subsubsection{The Quality of External Auditor Hired by SAIs and Good Governance}

In the performance of the SAIs functions, the office of Auditor General supervises the external audit functions of government units by hiring external auditors for audit of the MDAs office annually, and report their findings to the public account committees (PAC) of the National Assembly [12]. However, despite the engagement of the external auditors to assess the financial operations of MDAs, corruption and other irregularities are still endemic and continue to affect the economic and social health of the nation [33]. The ability to achieve this set objective depend on audit quality. Any influence on the auditors' independence may have negative impact audit quality. The objective of external auditor may be compromised, if the audit quality is impaired. Chepkorir [34] examined the factors that influence auditor's independence and accountability in different countries using different approaches. The study found that the role of management in the selection of experienced and quality external auditors is the major determinant of auditors' independence. In addition, the stakeholder's interest was significantly protected with the implementation of good corporate governance in the capital market activities [35]. It is apparently clear that the quality of external auditors hired by the SAIs has significantly influenced the independent of institution towards effective and efficient performance. However, evidence on this subject matter is scarce [12]. Therefore, this study used the empirical analysis to examine the relationship between quality of external auditors hired by SAIs and good governance. The study proposed the hypothesis as follows:

\section{$\mathrm{H}_{2}$. There is a significant relationship between quality of external auditor hired by SAIs and good governance in Nigeria.}

\section{Methodology}

The research methodology was based on the description of the systematic inquiry, process, sample collection and analysis carried out in the research, according to Martin and Guerin [36]. Meanwhile, the main purpose of this study is to examine how the independence of SAI influence good governance in Nigeria. Thus, the research questions stated are "what are the influence of underfunding of SAIs on good governance and how does the external audit quality affect good governance in Nigeria". To collect data from the office of the auditor general for the federation and the PAC National Assembly, a self-administered questionnaire was formulated which comprises two parts (profile of the respondents and main variable parts). Respondents were asked to evaluate the items of various variables such as SAI under-funding, external audit quality and good governance based on 5 -point likert scales that vary from strongly disagree (SD: 1) to strongly agree (SA: 5). Therefore, this study distributed 150 questionnaires by purposeful sampling methods to target respondents and through face-to-face, as it is the simplest way to do with a large number of sample sizes, as indicated by Hair et al [37]. As it was a major transformation of statistical data into a linear mix of structures, both descriptive and inferential analysis were used [38]. The survey study uses Statistical Packages for Social Science (SPSS version 25) and Structural Equation Modeling (SEM) to investigate how SAI - independent variable - affects the public sector of good governance in Nigeria.

\section{Data Analysis and Interpretation of Results}

\subsection{Response Rate of Distribution}

In this study, a total number of 150 questionnaires were distributed to the target respondents, of which 114 questionnaires were received. Four (4) copies of questionnaires were removed because of the respondent's incorrect and incomplete response to the questionnaire. 110 questionnaires were found to be accurate for data processing after the completion of questionnaire screening process, representing a 73 percent performance rate that was considered reasonable in terms of time, certainty, cost and geographical constraints. Table 1 indicates the summary of the response rate of the questionnaire survey distributed to the target respondents. 
Table 1. Response Rate of Distribution

\begin{tabular}{|c|c|}
\hline Descriptions & No of Respondents \\
\hline Distributed Questionnaires & 150 \\
\hline Retrieved Questionnaires & 114 \\
\hline Usable for further Analysis Questionnaires & 110 \\
\hline Unusable Questionnaires & 4 \\
\hline Response Rates & $73 \%$ \\
\hline
\end{tabular}

\subsection{Descriptive Statistics of the Variables}

Table 2 presents the opinion of the respondents on all SAIs independence variables on good governance in Nigeria. The findings revealed the characteristics of good governance in the public sector, under-funding of SAIs, and the external auditor's quality. With an average of 3.94, the average score of mean and standard deviation is moderately good and the standard deviation is 0.849 , suggesting that independent variables in Nigeria are vulnerable to good governance. Therefore, the highest mean value for the "good governance" construct is 3.94, followed by "external auditor quality" with a mean of 3.92 . The smallest average of the "underfunding of SAI" construction is 3.87 . The respondents are therefore more likely to claim that good governance is impaired on the basis of the high response rate on the obstacle factor of SAIs because the standard deviation of SAI underfunding is less varied.

Normality testing has also been used in statistical studies and multivariate data analysis as an important and popular technique in which many tests have been proposed. It is therefore important for researchers to analyze the normality of their distribution of data before progressing to the stage of study [37, 38]. For this analysis, the test for normality was conducted using skewness and kurtosis as indicated by Tabaniche and Fidel [39]. Therefore, the skewness and kurtosis values of the variables are within the \pm 2.58 appropriate range. Therefore, the entire constructs are normal.

Table 2. Descriptive Statistics and Normality Test

\begin{tabular}{ccccc}
\hline Constructs & Mean & SD & Skewness & Kurtosis \\
\hline Good Governance & 3.940 & .849 & -1.42 & .93 \\
Under-funding of & 3.874 & .803 & -1.07 & .243 \\
$\quad$ SAI & & & & \\
$\begin{array}{c}\text { External Audit } \\
\text { Quality }\end{array}$ & 3.920 & .890 & -1.32 & 1.27 \\
\hline
\end{tabular}

\subsection{Assessing of Model Fit}

The study's measurement model was discussed in Figure 1. The fitness of the model was revealed by analysing data via the structural equation model. The composite reliability should be greater than 0.7 by the rule of thumb and the average variance extracted (AVE) should be greater than 05 [38]. The model shows the variables' indicators (loadings). Some items are not loaded as they do not fulfil the criteria. This led the researcher to discard such indicators and the final measurement model is shown below.

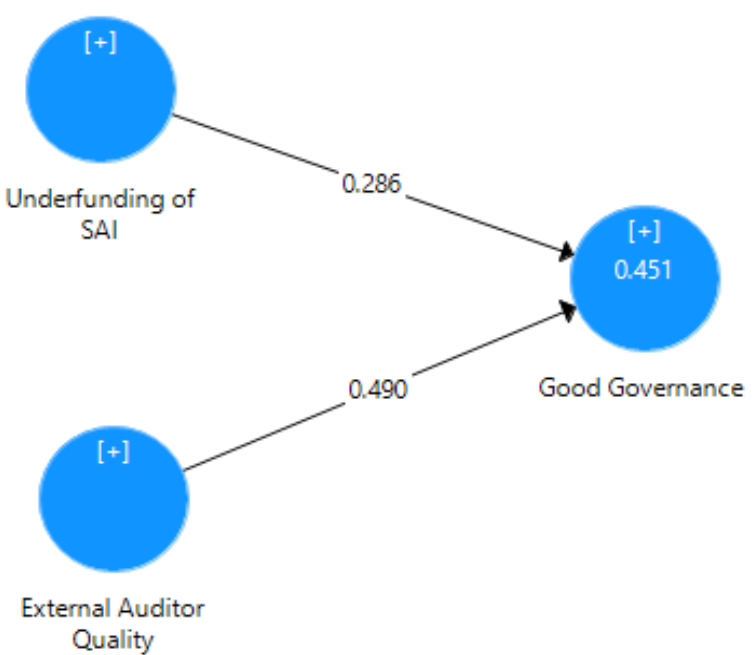

Figure 1. Measurement Model

\subsection{Validity and Reliability of the Research instrument}

Validity refers to the degree to which a score reflects the definition of a construct correctly and truthfully [40]. Similarly, Sekaran and Bougie [41] defined validity analysis as an assessment of how efficient a research instrument developed, measures a particular construct it intended to measure. Composite reliability (CR) and average variance extracted (AVE) as suggested by Garson [42] were determined using the PLS-SEM algorithm to assess the internal reliability and validity of all the constructs of this analysis, as shown in Table 3 below.

Table 3. Construct Reliability and Validity

\begin{tabular}{|c|c|c|c|}
\hline Constructs & $\begin{array}{c}\text { Composite } \\
\text { Reliability }\end{array}$ & AVE & R Square \\
\hline Good Governance & 0.934 & 0.676 & 0.451 \\
\hline Under-funding of SAI & 0.860 & 0.512 & \\
\hline $\begin{array}{c}\text { External Audit } \\
\text { Quality }\end{array}$ & 0.885 & 0.675 & \\
\hline
\end{tabular}

From the table above, CR and AVE of all constructs as computed were above the threshold of 0.7 and 0.5 respectively as suggested by [38]. Therefore, it is concluded that all the construct were measured by the selected indicators which confirmed the validity and reliability of the research instrument.

Table 4. Discriminant Validity

\begin{tabular}{|c|c|c|c|}
\hline Constructs & EAQ & PSP & UFS \\
\hline External Audit Quality & 0.822 & & \\
\hline Good Governance & 0.622 & 0.822 & \\
\hline Under-funding of SAI & 0.464 & 0.513 & 0.716 \\
\hline
\end{tabular}

Note: The bolded diagonal numbers represents the square root of the AVE of each constructs.

Table 4 presents the result of discriminant validity. The numbers that are bolded represent the square root of AVE 
of each variable and are higher than their correlation with other variable as can be observed in the table. The square root of AVE are greater than the correlations among the constructs, as suggested by Fornell-larcker [43] criterion. This means that a construct should be unique and capture phenomena not represented by other constructs in the model as confirmed [38].

\subsection{Bootstrapping Analysis}

It is important to carry out a bootstrapping analysis to determine the independence of SAI towards good governance in Nigeria. Bootstrapping was done by using 5,000 subsamples using 110 cases. Based on the result, the figure 2 shows how the magnitude and significance of the structural paths are consistent.

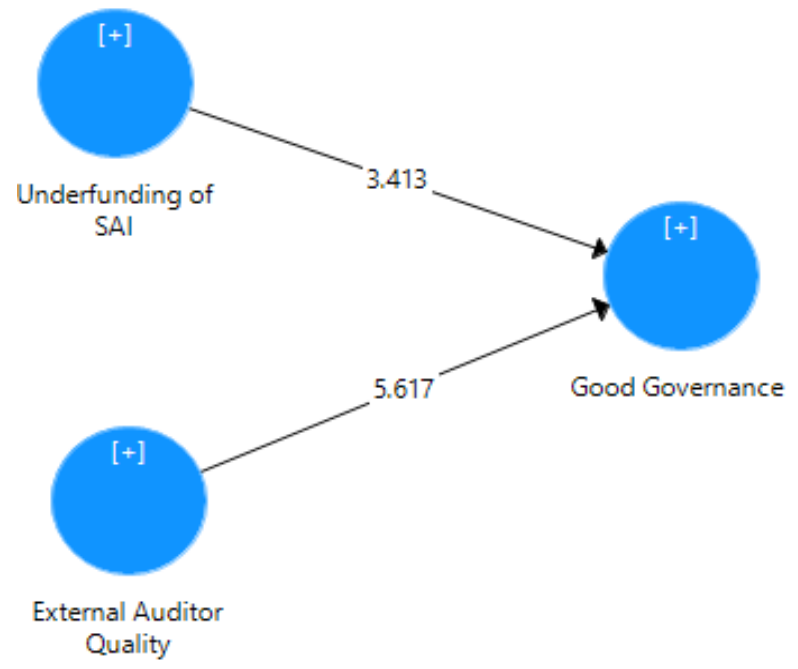

Figure 2. Structural Model

\subsection{Test of Hypotheses}

Table 5 presents the path coefficient, which indicates the coefficient value, standard error, $\mathrm{R}$ Square and Decision Rule of hypotheses tested in the study.

Table 5 shows that underfunding of SAI has T-value of $-3.413^{* *}$ with the corresponding beta coefficient of -0.286 .
This means underfunding of SAI affected the good governance in Nigeria. Therefore, the hypothesis stated that, there is a significant influence of underfunding of SAI on good governance in Nigeria. Hence, the hypotheses $\left(\mathrm{H}_{1}\right)$ is supported. Likewise, the Table 5 also revealed that external audit quality has $\mathrm{t}$-value of $-5.617^{* * * *}$ which is negatively significant at $1 \%$ with the corresponding coefficient of -0.490 . This also implies that external audit quality has negative and significant effect on good governance of Public Sector in Nigeria. Therefore, the second hypothesis, which inter alia stated that external audit quality has significant effect on good governance in Nigeria, is accepted.

\subsection{Effect Size}

It is essential to examine the effect, size and predictive relevance for the relationships between independent of supreme audit institutions and good governance of public sector in Nigeria. Table 6 below shows the result of effect size and predictive relevance of the study.

The effect size measured as the increase in R-squared of the variable to which the direction is related as shown in Table 6, compared to the proportion of unexplained variance of the variable [46]. R-square change is the change in $\mathrm{R}^{2}$ when a causal factor is removed from the model. The f-square coefficient is constructed according to Cohen, [44] and Ringle, and Henseler [40] as $\left(\mathrm{R}^{2}\right.$ original $-\mathrm{R}^{2}$ omitted) / (1- $\mathrm{R}^{2}$ original). Effect size of each constructs is underfunding of SAI (0.11) and external auditors' quality (0.09). The rule of thumb according to Cohen [44] is that values of $0.02,0.15$ and 0.35 are said to be small, medium and large effects size respectively. Looking at the $\mathrm{f}^{2}$ as shown in the table 5 above, both the underfunding of SAI and external auditors quality have small effect on good governance of Public Sector in Nigeria as recommended by Hair et al. [38], the predictive relevance is achieved, when the $\mathrm{Q}^{2}$ is higher than zero. Hence, the result of the good governance $(0.289)$ show above zero, indicating that the model has predictive relevance.

Table 5. Testing of Hypotheses on Direct relationship

\begin{tabular}{|c|c|c|c|c|c|}
\hline Hypotheses & Beta & SE & T-values & P-Values & Decision \\
\hline Underfunding of SAI -> Good Governance & -0.286 & 0.084 & $-3.413^{* *}$ & 0.001 & Supported \\
\hline External Auditor Quality -> Good Governance & -0.490 & 0.087 & $-5.617^{* * *}$ & 0.000 & Supported \\
\hline
\end{tabular}

$* * * \mathrm{p}<0.01 ; * * \mathrm{p}<0.05 ; * \mathrm{p}<0.1$ 
Table 6. Effect Size on Direct relationship

\begin{tabular}{|c|c|c|c|}
\hline Constructs & Effect size (f $\mathbf{f}^{\mathbf{2}}$ & $\mathbf{Q}^{\mathbf{2}}$ & Decision \\
\hline External Auditor Quality & 0.09 & & Small \\
\hline Underfunding of SAI & 0.11 & & Small \\
\hline Good Governance & & 0.289 & \\
\hline
\end{tabular}

\section{Conclusions and Recommendations}

The study examines the factors hindering the independence of supreme audit institution towards good governance in Nigeria. Specifically, two factors were examined in this study includes underfunding of SAI and quality of external auditor hired by SAI. PLS-SEM were used to analyze the stated hypotheses. The result of the analysis indicates that underfunding of SAI and quality of external audit hired for the auditing exercise significantly hindered their independent and eventually affects the good governance of public sector in Nigeria. The study is also supported by the reports evidence of Inyang [9] that underfunding of SAIs is a deliberate attempt to conceal fraud and other financial irregularities that result to the bad governance in Nigeria, to the extent that the budget of the supreme audit institution is controlled by the executive arms of government. Therefore, the constitutional provision, which impairs the independent of SAIs, should be removed to enable its financial autonomy and this will eventually enhance the checks and balances in the accountability and transparency process. Furthermore, thorough investigation should be conducted on the background information of the external auditor hired by the SAI to conduct their statutory audit role to prevent ineffective and inefficient governance of public sectors in Nigeria.

It is necessary for the SAIs to become the pillar of the country's reputation in auditing government revenue and expenditure, overseeing financial integrity and the credibility of information given to the nation. As it was revealed during the data collection process, regular and well-designed audit of the SAIs provide better opportunities to discover the loopholes and weaknesses in the inefficient management of public resource by the executive. SAIs need to enhance a sound financial management practice and also act as deterrent institution against corruptions and other irregularities in the public sectors environment. Future studies may further examine the procedure for the appointment and promotion of external audit head in the auditor general office to curb the issue of influence and the constitutional power of SAI.

\subsection{Limitations of the Study}

Based on the limitations of this study, despites many contribution of this present study to the body of relevant knowledge, few limitations were discussed. This mainly focused on the under-funding of SAI and appointment of external auditor as the causes for the good governance. However, there are other factors that responsible for good governance. In addition, this study only considered agency theory and resource dependence theory to examine the financial reporting quality. Thus, there are other relevant theories (stakeholder theory) that can examine the relationship. Finally, this study is only limited to the Auditor General office in Nigeria. Thus, other African countries can be capture. Nevertheless, the limitations of this study could not sidetrack the contribution of this study.

\section{REFERENCES}

[1] Lassou, P. J., Hopper, T., \& Ntim, C. G., "Supreme audit institutions and public financial management in Benin, a Francophone African country: A civic public and legitimacy analysis," SSRN Electronic Journa, 2019. https://doi.org/10.2139/ssrn.3311761

[2] Javed, M., \& Zhuquan, W., "Analysis of accounting reforms in the public sector of Pakistan and adoption of cash basis IPSAS," Universal Journal of Accounting and Finance, 6(2), 47-53, 2018. https://doi.org/10.13189/ujaf.2018.060203

[3] Udeh, S. N., \& Elom, J. O., "Challenges of Performance Auditing in Public Sector Accountability in Nigeria: A Study of the Office of Auditor General," ESUT Journal of Accountancy, 7(1), 204-216, 2016.

[4] Kayrak, M., "Evolving challenges for supreme audit institutions in struggling with corruption," Journal of financial crime, 2008.

[5] Yiannoulis, Y. K., "Literature review on the Hellenic auditing and accounting environment before, during and after the crisis period. Universal Journal of Accounting and $\begin{array}{lll}\text { Finance, } & 7(2), & 43-49,\end{array}$ https://doi.org/10.13189/ujaf.2019.070202

[6] Kim, N., "Supreme audit institution and democracy: The function of the board of audit and inspection (BAI) of Korea for democratization," Public Policy and Governance, 141-157, 2017. https://doi.org/10.1108/s2053-7697201700 00028006

[7] Margaret, A. R., "Critical evaluation of internal control environment situation of Nigeria public audit," Journal of Modern Accounting and Auditing, 15(9), 2019. https://doi.org/10.17265/1548-6583/2019.09.003

[8] Odia, J. O., "Performance Auditing and Public Sector Accountability in Nigeria: The Roles of Supreme Audit Institutions (SAIs)," Asian Journal of Management 
Sciences \& Education Vol, 3, 2, 2014.

[9] Inyang, W., "Under-funding the supreme audit institution amidst the rising unauthorized extra-budgetary expenditures in Nigeria: is deliberate under-funding a fraud-concealing device". Research Paper Series, Research Journal of Finance and Accounting, 7(16), 2016.

[10] Ademola, L. S., Ayoib B. C., \& Popoola, J. M., "The forensic accountants' skills and ethics on fraud prevention in the Nigerian public sector," Academic Journal of Economics Studies. 3(2), 77-85, 2017

[11] Lateef, S. A. Rashid, N. M., Mubaraq, S., \& Abubakar, U. F., "Capability Requirements on Fraud Prevention in the Nigerian Public Sector: The perception of Professional Accountant," 2019.

[12] Emeka, E. E., \& Josephine, E. C., "Auditors' independence and corruption alleviation in the Nigerian public service," Finance \& Accounting Research Journal, 1(1), 2020. https://doi.org/10.51594/farj.v1i1.20

[13] Dakhlallh, M. M., "Audit committee and Tobin's Q as a measure of firm performance among Jordanian companies," Journal of Advanced Research in Dynamical and Control Systems, 12(1), 28-41, 2020. https://doi.org/10.5373/jardcs /v12i1/20201005

[14] INTOSAI, S. (2018). International Organization of Supreme Audit Institutions: Statutes, 2018.. ac-rada. gov. ua Retrieved from http://www. ac-rada. gov. ua/control/main/uk/publish/article/232209.

[15] United Nations, "Promoting the Efficiency, Accountability, Effectiveness and Transparency of Public Administration by Strengthening Supreme Audit Institutions." Resolution Adopted by the General Assembly of United Nations, 2011. (GA Resolution A/66/209), http://daccess-ods.un.org/ TMP/4913941.32375717.html, Accessed May 11, 2013.

[16] Lassou, P.J.C., Tsamenyi, M. and Hopper, T., "Political economy of accounting and governance in Africa," Paper presented at Critical Perspectives on Accounting Conference, July, 79, 2014.

[17] Hopper, T., Soobaroyen, T. and Lassou P.J.C., "Globalisation, accounting and developing countries," Critical Perspectives on Accounting, 43,125-148, 2017.

[18] Elad, C., "The development of accounting in the franc zone countries in Africa," The International Journal of Accounting, 50(1), 75-100, 2015. https://doi.org/10.1016/j. intacc.2014.12.006

[19] Fyson, S. "Accounting and development: The role of donors from policy to practice. Handbook of Accounting and Development," $\quad$ pp. $15 \quad-\quad 35,2012$. https://doi.org/10.4337/9781781002605.00007

[20] Akhidime, A., \& Izedonmi, F., "Challenges of supreme audit institutions: perspective of Auditor-General of Nigeria," The USV Annals of Economics and Public Administration, 12(1 (15)), 183-189, 2013.

[21] [21] Kasum, S. A., "Proceedings of the 1st International Conference on Governance, Fraud Ethics and Social Responsibility," June 11-13, 2009 "Government Auditing Standards (the Newswatch Magazine (2001). Auditor-General Retired. April23, 2009.
[22] INTOSAI, "Structure of Government Auditing Standards 19th International Conference on New Developments in Government Financial Management," 2005.

[23] Khan, M. A., "Role of audit in fighting corruption. In Ethics, Integrity, and Accountability. In the Public Sector: Re-building Public Trust in Government through the Implementation of the UN Convention against Corruption," Russia: Ad Hoc Group Meeting On, 2008.

[24] Ijeoma, N. B. \& Nwufo, C. I., "Impediments of the audit function in the public sector: a critical analysis of the constraints of Auditor-General for the federation of Nigeria," International Journal of Economics, Commerce and Management. 3(1): 1-25, 2015.

[25] Abdullah, H. \& Valentine, B., "Fundamental and ethics theories of corporate governance," Middle Eastern Finance and Economics (4): 1-9, 2009. Retrieved from http://www.eurojournals.com /MEFE.htm

[26] Wisdom, O., "Impact of Public Sector Auditing in Promoting Accountability and Trasparency in Nigeria," Journal of Internet Banking and Commerce, 22(3), 1-8, 2017.

[27] Wolfe, D. T., \& Hermanson, D. R., "The fraud diamond: Considering the four elements of fraud," 2004.

[28] Cressey, D. R., "The criminal violation of financial trust. American Sociological Review 15(6),738,1950.https://doi. org/10.2307/2086606

[29] ABDULLAHI, R., \& MANSOR, N., "Fraud triangle theory and fraud diamond theory. Understanding the convergent and divergent for future research," International Journal of Academic Research in Accounting, Finance and Management Sciences, 5(4), 2015. https://doi.org/10.6007/ ijarafms/v5-i4/1823

[30] Nikodem, A., "Constitutional regulation of supreme audit institutions in Central Europe in a comparative perspective," Managerial Law, 46(6), 32-52, 2004.https://doi.org/10.110 $8 / 03090550410771044$

[31] Wang, V. \& Rakner, L., "The accountability function of supreme audit institutions in Malawi, Uganda and Tanzania," Michelsen Institute, 2005.

[32] Adewusi, A. O., "Motivation and Ethics: Essential Factors for Sustainable Public Service Delivery in Nigeria," Journal of Organizational Studies and Innovation, 3(1), 19-33, 2016.

[33] Uzochukwu, M., "Corruption in Nigeria: Review, Causes, Effects, and Solutions," https://soapboxie.com/world-politi cs/Corruption-in-Nigeria, 2019.

[34] Chepkorir. C., "Factors Influencing Auditor's Independence and Account-ability, A Case Study of KTDA Affiliated Tea Factories in Bomet and Kericho County, Kenya. A research project submitted to school of business and economics in partial fulfillment for the award of degree in business management (accounting option), 2013., \& Maasai Mara University.

[35] Mustapha, U. A., Rashid, N., Bala, H., \& Musa, H., "Corporate governance and financial performance of Nigeria listed banks," Journal of Advanced Research in Dynamical and Control Systems, 12(1), 5-10, 2020. https://doi.org/10.5373/jardcs/v12i1/20201002 
[36] Martin, C. S., \& Guerin, D. A., "Using research to inform design solutions. Journal of Facilities Management, 4(3), 167-180, 2006.https://doi.org/10.1108/1472596061067375 1

[37] Hair, J. F., Black, W., Babin, B., \& Anderson, J. "Multivariate data analysis: A global perspective. New Jersey: Pearson Prentice Hall," 2016.

[38] Hair, J. F., Hult, G. T. M., Ringle, C., \& Sarstedt, M. “A primer on partial least squares structural equation modeling (PLS-SEM)," Washington DC: SAGE Publications, Incorporated, 2014.

[39] Tabachnick, B. G., \& Fidell, L. S., "Multivariate analysis of variance (MANOVA)," International Encyclopedia of Statistical Science, 902-904, 2013. https://doi.org/10.1007/978-3-642-04898-2_394

[40] Zikmund, W. G., Carr, J. C., \& Griffin, M., "Business Research Methods (Book Only)," Cengage Learning, 2013.

[41] Sekaran, U. \& Bougie "Research methods for business: A skill building approach (8th ed.)," New York: John Wiley and Sons Ltd, 2012.

[42] Garson, G. D., "Partial least squares. Regression and structural equation models," 2016.

[43] Fornell, C., \& Larcker, D. F., "Structural equation models with unobservable variables and measurement error: Algebra and statistics," Journal of Marketing Research, 18(3), 382-388, 1981. https://doi.org/10.1177/0022243781 01800313

[44] Cohen, J., "Statistical power analysis for the behavioral sciem'es," 1988.

[45] Ringle, C. M., \& Henseler, J. "Exploring causal path directionality for a marketing model using Cohen's path method," 2007.

[46] Chin, W.W., "The Partial Least Squares Approach to Structural Equation Modeling," In Marcoulides, G.A. (Ed.), Modern Methods for Business Research. Lawrence Erlbaum, Mahwah, NJ, pp. 295-336, 1998.

[47] Iyoha, F., \& Oyerinde, D. "Accounting infrastructure and accountability in the management of public expenditure in developing countries: A focus on Nigeria. Critical Perspectives on Accounting, 21(5), 361-373, 2010. https://doi.org/10.1016/j.cpa.2009.06.002

[48] Van Zyl A., Ramkumar, V. \& De Renzio, P., "Responding to the challenges of supreme audit institutions: Can legislature and civil society help? U4 Anti-Corruption Centre, Chr. Michelsen Institute (CMI)," 2009.

[49] Seyfried, M., "Setting a fox to guard the henhouse? Determinants in elections for presidents of supreme audit institutions," Managerial Auditing Journal, 31(4/5), 492-511, 2016. https://doi.org/10.1108/maj-03-2015-1168

[50] M. M. Dakhlallh, N. Rashid, W. A. Wan Abdullah, and H. J. Al Shehab, "Audit committee and Tobin's Q as a measure of firm performance among Jordanian companies," J. Adv. Res. Dyn. Control Syst., vol. 12, no. 1, pp. 28-41, 2020, doi: 10.5373/JARDCS/V12I1/20201005.

[51] N. A. Hamid et al., "Determinants of tax compliance among individual tax payers in Malaysia," J. Adv. Res. Dyn. Control Syst., vol. 12, no. 3, pp. 316-321, 2020, doi: 10.5373/JARDCS/V12I3/20201196.

[52] U. A. Mustapha, N. Rashid, H. Bala, and H. Musa, "Corporate governance and financial performance of Nigeria listed banks," J. Adv. Res. Dyn. Control Syst., vol. 12, no. 1, pp. 5-10, 2020, doi: 10.5373/JARDCS/V12I1/20201002

[53] M. M. Dakhlallh, N. Rashid, W. A. Wan Abdullah, H. K. Qawqzeh, and A. Mustafa Dakhlallh, "Accrual-based earnings management, real earnings management and firm performance: evidence from public shareholders listed firms on Jordanian's stock market," J. Adv. Res. Dyn. Control Syst., vol. 12, no. 1, pp. 16-27, 2020, doi: 10.5373/JARDCS/V12I1/20201004.

[54] N. P. N. A. N. Azmi, I. Tarmuji, N. A. Hamid, Z. A. Rasit, and N. Rashid, "Tax compliance motives among grab car drivers in Malaysia," J. Crit. Rev., vol. 7, no. 11, pp. 445451, 2020, doi: 10.31838/jcr.07.11.80.

[55] A. B. Ado, N. Rashid, U. A. Mustapha, and L. S. Ademola, "The financial determinants of earnings management and the profitability of listed companies in nigeria," J. Crit. Rev., vol. 7, no. 9, pp. 31-36, 2020, doi: 10.31838/jcr.07.09.06. 